\title{
The ecological interaction of the mountain pine beetle and jack pine budworm in the boreal forest
}

\author{
by Lindsay J. Colgan ${ }^{1}$ and Nadir Erbilgin ${ }^{1,2}$
}

\begin{abstract}
As climate change facilitates the range and host expansion of insect species into new ecosystems, the development of new strategies for managing and preventing biological invasion is receiving considerable interest. In recent years, the range of the mountain pine beetle (Dendroctonus ponderosae Hopkins) has expanded from lodgepole pine-dominated forests east of the Rocky Mountains into lodgepole x jack pine hybrid forest of western Alberta, and may soon invade jack pine forests of the boreal. Our understanding of factors contributing colonization of jack pine by mountain pine beetle is far from complete and several factors may limit its spread in these forests, including tree resistance and competitors. Among these, the jack pine budworm (Choristoneura pinus pinus Freeman) is one of the most important insect enemies of jack pine and an outbreak defoliator that potentially weakens jack pine trees, which may make them more susceptible to MPB attacks. To develop effective management strategies in the face of the short-run impacts of climate change, we need an in-depth understanding of factors influencing establishment and survival of the beetle in jack pine forests.
\end{abstract}

Key words: Choristoneura pinus pinus, Dendroctonus ponderosae, jack pine, range expansion, invasion biology, climate change in the boreal forest, conifer-mediated interactions, tree induced defences, tripartite interactions

\begin{abstract}
RÉSUMÉ
Compte tenu que les changements climatiques facilitent lexpansion de l'aire de distribution des hôtes et des insectes dans de nouveaux écosystèmes, le développement de nouvelles stratégies de contrôle et de prévention des invasions biologiques reçoit beaucoup d'attention. Au cours des dernières années, laire de distribution du dendroctone du pin ponderosa (Dendroctonus ponderosae Hopkins) s'est étendu des forêts dominées par le pin lodgepole à lest des Rocheuses vers les forêts hybrides de pin lodgepole x pin gris de l'ouest de l'Alberta et pourrait sous peu envahir les pinèdes grises de la forêt boréale. Notre compréhension des facteurs contribuant à la colonisation du pin gris par le dendroctone du pin ponderosa est loin dêtre complète et plusieurs facteurs pourraient modifier sa dispersion dans ces peuplements, dont la résistance des arbres et la compétition. Parmi ces derniers, la tordeuse du pin gris (Choristoneura pinus pinus Freeman) est l'un des plus importants insectes ravageurs du pin gris pouvant engendrer une épidémie qui serait susceptible d’affaiblir les pins gris, les rendant ainsi plus exposés aux attaques du dendroctone. Afin délaborer des stratégies effectives de contrôle face aux impacts à court terme des changements climatiques, nous devons approfondir notre compréhension des facteurs qui influencent létablissement et la survie du dendroctone dans les pinèdes grises.
\end{abstract}

Mots clés : Choristoneura pinus pinus, Dendroctonus ponderosae, pin gris, expansion de la distribution, biologie de l'invasion, changements climatiques dans la forêt boréale, interactions entre les conifères, défenses induites chez larbre, interactions tripartites

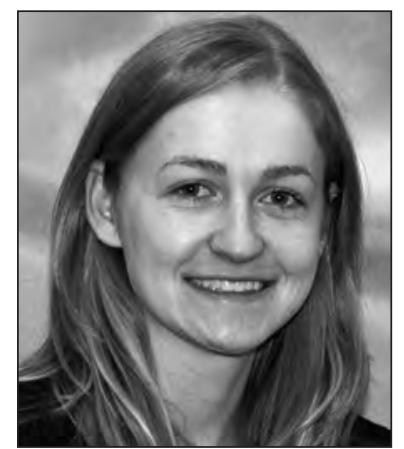

Lindsay J. Colgan

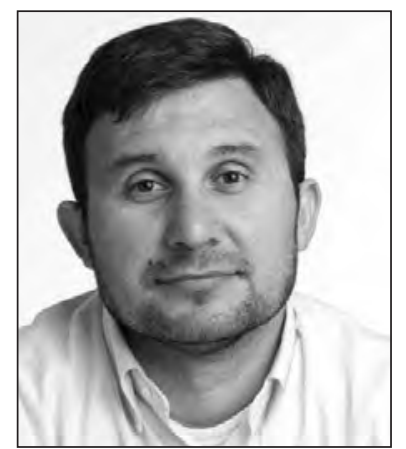

Nadir Erbilgin

\section{Background}

Climate change in recent decades has led to shifts in the ranges of insect, bird, and marine species (Parmesan and Yohe 2003, Parmesan 2006). Species range expansions are a short-run effect of climate change that could have large impacts on the dynamics of newly colonized ecosystems. In North America, one species expansion of great concern is that of the mountain pine beetle (Dendroctonus ponderosae Hopkins [Coleoptera: Curculionidae, Scolytinae]; MPB). Since the 1970s, the climatically suitable habitat for the MPB has increased by $75 \%$ and beetle populations have reached epidemic levels in areas where they usually do not (Carroll et al. 2006). MPB is the most destructive insect in Canadian pine forests and now there is great concern about its eastward

\footnotetext{
${ }^{1} 442$ Earth Sciences Building, Department of Renewable Resources, University of Alberta, Edmonton, Alberta T6G 2E3

${ }^{2}$ Author to whom correspondence should be addressed. E-mail: erbilgin@ualberta.ca
} 
spread as there are no host-related impediments in boreal and eastern pines (Cerezke 1995, Rice et al. 2007, CFS 2008).

Species that have naturally expanded their range and those translocated by humans can be studied in the same theoretical framework of invasion ecology as similar factors influence their establishment in new ecosystems (Thuiller et al. 2007): their biological characteristics, community structure, and ecosystem invasibility. Non-native species that establish are of interest for the integrity of natural and managed ecosystems and pest species are of particular concern as they may become invasive in the new ecosystem with devastating impacts.

The MPB has been generally limited to lodgepole pine (Pinus contorta Dougl. ex Loud. var. latifolia Engelm.)-dominated forests west of the Rocky Mountains in Canada but over the last decade populations have moved into higher elevations (Carroll et al. 2006) and eastward into lodgepole $\times$ jack pine hybrid forests of northern Alberta and as far east as Slave Lake (ASRD 2009). Based on the speed of its eastward movement, it is likely that the MPB will invade jack pine (Pinus banksiana Lamb.)-dominated forests of the boreal. If it successfully establishes as an outbreak species, the beetle could cause serious ecological and economic impacts when favourable conditions prevail (Logan et al. 2003, CFS 2008).

In a new ecosystem, invasive species encounter a suite of organisms with which they have not previously interacted that could influence their survival and spread. Such inter-specific relationships are critical in understanding ecosystem dynamics and resilience with the uncertainty of global change. Researchers have made many forecasts of global change impact for forests (Kurz et al. 2008, Malhi et al. 2010, Rammig et al. 2010) and individual species (e.g., Goldblum and Rigg 2005, Carroll et al. 2006, Bronson et al. 2009), but few have focused on the influences of inter-specific interactions despite their importance (Van der Putten et al. 2010).

In jack pine forests, MPB will indirectly interact with native organisms, including an outbreak defoliator, the jack pine budworm (Choristoneura pinus pinus Freeman [Lepidoptera: Tortricidae]; JPBW). The JPBW's range does not extend into the Rocky Mountains and it is uncommon for the MPB to encounter an outbreak defoliator in lodgepole pine forests of British Columbia (Duncan 2003). Additionally, an outbreak bark beetle is absent from jack pine forests, although secondary bark beetles (e.g., pine engraver Ips pini Say) are present and may kill small numbers of trees. The interaction between JPBW and MPB is important because as two outbreak species, fluctuations in their damage and population sizes have the potential to impact jack pine host availability and suitability. Understanding the relationship between these two insects is valuable in understanding how a native organism may influence the susceptibility of jack pine and affect the invasive potential of MPB.

The goal of this paper is to highlight a short-term impact of climate change: the expansion of the MPB into the boreal forest and its indirect interaction with JPBW on jack pine. This is a new and important area in forest biology that could contribute to management decisions. Since little is known about how MPB will behave in the jack pine ecosystem, it is important to first understand its relationships with individual organisms. We limit our discussion to the relationship of MPB with JPBW on jack pine as addressing the response of all species in the boreal ecosystem in a theoretical discussion is an unrealistic and highly speculative task. We investigate this interaction by examining the natural history and population dynamics of JPBW and MPB, explore several scenarios of JPBW and MPB at different population densities in the boreal forest, and address areas for research in the future.

\section{Jack Pine Budworm \\ Natural history}

The JPBW is one of the primary defoliators of jack pine in Canada's boreal forest (McCullough and Kulman 1991). It is principally hosted by jack pine but also feeds on Scots (Pinus sylvestris L.) and red ( $P$. resinosa Ait.) pines when they are mixed with jack pine (Kulman and Hodson 1961). Host trees are mature, flowering individuals, generally over 20 to 30 years old.

The JPBW is a univoltine species that overwinters in bark crevasses as second instar larvae in an obligate diapause (McCullough 2000). In the spring, larvae feed for about six weeks, first on pollen cones and later on new foliage, developing through seven instars (Nealis 1995). In July, larvae pupate and adults emerge one to two weeks later (McCullough 2000). Females produce pheromones to attract males for mating (Sanders 1971) and after copulation, lay eggs on older needles. Eggs hatch in late summer and first instar larvae move to bark crevasses where they moult and form winter hibernacula without feeding. JPBW survival and success appear to be influenced by tree nutrition, site conditions, natural enemies, and defensive host chemicals (Nealis and Lomic 1994, Wallin and Raffa 1999, McCullough 2000). Results from McCullough and Kulman (1991) suggest that changes in needle monoterpenes do not greatly impact larval feeding but negatively affect adult fecundity.

\section{Population dynamics}

The JPBW persists at low populations in open crown jack pine forests (Kulman et al. 1963). The presence of pollen cones on host trees affects population density in the spring and strongly influences the survival of early instar larvae (Nealis and Lomic 1994). Outbreaks last two to four years and occur at six-to 12-year intervals, depending on the region and conditions (McCullough 2000). In Wisconsin, JPBW outbreaks at five-, six-, and 10-year intervals (Volney and McCullough 1994) and in Saskatchewan at approximately 10-year intervals (Volney 1988). The size of an outbreak is strongly associated with habitat type; shorter cycles are associated with dry and nutrient-poor sites (Volney and McCullough 1994). Weather, fire and water availability likely drive longer 10-year outbreak cycles, and weather, site conditions and some other unknown external factors likely drive shorter five- and sixyear cycles (Volney and McCullough 1994). Volney (1988) suggested that the observed increase in outbreak size is due to a greater proportion of susceptible age classes on the landscape as a result of fire suppression. There are currently no significant outbreaks in the Prairie Provinces but for the last few years there have been areas of defoliation in Ontario (NRCan 2009; Taylor Scarr, Ontario Ministry of Natural Resources, personal communication).

During population outbreaks, severe defoliation can result in reduced growth, top kill, and tree mortality (Kulman et al. 1963) but such defoliation rarely persists in a stand for more than one year (Gross and Meating 1994, McCullough et al. 1996). Outbreaks collapse quickly due to high parasitism of late larval stages (Nealis 1991) and because there is a negative 
feedback between jack pine pollen cone production and previous defoliation (Nealis and Lomic 1994). Data from Ontario and Michigan reveal 15\% tree mortality in an outbreak and $15 \%$ to $20 \%$ of top-kill trees killed in subsequent outbreaks (Gross 1992, Conway et al. 1999).

Jack pine-dominated ecosystems have evolved with JPBW defoliation as a periodic disturbance. Additionally, the accumulation of deadwood fuels and dense crowns of jack pine support fires that open the serotinous cones of jack pine and perpetuate even-aged stands (McCullough 2000). Historically, forest fires have left a variety of age classes on the landscape and limited the proportion of stands susceptible to JPBW.

\section{Mountain Pine Beetle Natural history}

The MPB is an outbreak bark beetle species that attacks pine species and is primarily hosted by lodgepole, ponderosa $(P$. ponderosa P. Laws. ex C. Laws) and western white (P. monticola Dougl. ex D. Don) pines in its range (Safranyik and Carroll 2006). The beetle is found in forests from the Pacific Coast east to the Black Hills of South Dakota, and from northern British Columbia and western Alberta south to northwestern Mexico (Wood 1982). It attacks mature trees of varying diameter and the quality of hosts varies with beetle population density (Elkin and Reid 2010).

Beetles use aggregation pheromones to attack en masse so as to exhaust a tree's defences, access phloem tissue, and kill the host tree. The host tree must die for successful reproduction (see Ecology section below). Pioneer females use visual and olfactory cues to select host trees (Safranyik and Carroll 2006). Once a host is chosen, females begin to construct galleries and initiate mass attack by converting $\alpha$-pinene to the aggregation pheromone trans-verbenol (Borden et al. 1983). After a few days, anti-aggregation pheromones, such as verbenone (Hunt and Borden 1990), divert beetles to other trees, optimize attack density, and reduce intra-specific competition (Berryman et al. 1985, Safranyik and Carroll 2006). The MPB is associated with a variety of mutualistic fungi that facilitate beetle establishment by weakening tree defences and disrupting transpiration, as well as provide a nutritional supplement for larvae and teneral adults (Paine et al. 1997, Bleiker and Six 2007).

Larvae do not have a winter diapause but increase their cold tolerance through the autumn by accumulating antifreeze proteins and polyhydric alcohols (e.g., glycerol, sorbitol) in their haemolymph (Bentz and Mullins 1999) and resume feeding in the spring, or early summer in high latitudes, as soon as temperatures are warm enough. Larvae undergo four instars, pupate in early summer, and new-generation adults emerge and fly to new host trees from late June to August depending on the latitude, elevation, and climate. Once new host trees are colonized, female beetles excavate egg galleries, mate, and lay eggs. After hatch, larvae begin to feed on the phloem.

\section{Population dynamics}

The population dynamics of the MPB can be delineated into four phases: endemic, incipient, epidemic, and post-epidemic (Safranyik and Carroll 2006). At endemic levels, small populations are unable to overcome the defences of vigorous trees and are constrained to attack lower-quality and smaller-diam- eter hosts. Host characteristics largely influence the choice of breeding site and beetles frequently target senescent trees or those weakened by insects or diseases. Mass aggregation is not usually achieved, and beetles are not successful in depleting tree defences. As a result, many trees are not killed but only partially attacked, commonly referred to as a strip kill. The size of the beetle population remains relatively constant from year to year and affected trees are scattered in a stand. At this stage, it is thought that natural enemies, such as parasitoids and predators, keep MPB populations under control (Safranyik and Carroll 2006).

In the incipient phase, the transition from endemic to epidemic levels, larger populations allow beetles to overcome the defences of healthy, larger, and more resistant hosts (Raffa and Berryman 1983, Safranyik and Carroll 2006). Attacked trees are clumped in discrete patches in stands as anti-aggregation pheromones divert flying beetles to adjacent uncolonized trees. More hosts are killed each year as MPB populations build.

At epidemic levels, beetles can successfully attack healthy stands and cause widespread mortality across the landscape. Epidemics in western Canada average ten years in duration and persist until hosts are depleted or unsuitably cold temperatures cause high mortality of overwintering larvae (Safranyik and Carroll 2006). During this stage, beetles fly long distances to find new suitable forest stands. In fact, on-going invasion of Alberta's lodgepole pine forests is a direct result of such long-distance dispersal of the beetles from BC. In the postepidemic phase, beetles continue to attack healthy hosts but declining populations result in many partially attacked trees and reduced generation sizes (Safranyik and Carroll 2006).

Generational success of MPB is greatly influenced by seasonal conditions. Weather can influence beetle dispersal and water deficits can influence tree resistance (Taylor et al. 2006). Cold snaps in the late fall and winter temperatures below $-40^{\circ} \mathrm{C}$ may result in high rates of larval mortality (Bentz and Mullins 1999).

Deadwood in MPB-killed stands promotes high-intensity fires that result in even-aged lodgepole pine regeneration. Prior to forest management, fires limited the proportion of stands suitable for MPB, limiting population growth. This pattern perpetuated a mosaic of age classes on the landscape (Taylor and Carroll 2004).

\section{Conifer-Mediated Interactions}

Conifers are subject to attack by a variety of organisms that use them for food, habitat, and oviposition. As a result, trees have evolved an array of defences to minimize damage by attackers. Constitutive defences are the "first tier of defence" (Franceschi et al. 2005) that are always maintained by a tree and function independently of damage (Karban and Baldwin 1997). If the organism is not deterred, the "second tier of defence" or a series of induced responses are triggered to further protect the plant (Franceschi et al. 2005). These physical and chemical changes occur over temporal scales of a few hours to the next season (Eyles et al. 2009). More specialized insects often have adapted to exploit conifer defences. For example, pines have specific induced responses to bark beetle attack (reviewed by Franceschi et al. 2005); however, bark beetles attack en masse to overwhelm a tree's defence system. As a result, bark beetles remain a major disturbance in coniferous forests (Berryman 1972, Paine et al. 1997, Raffa et al. 2008). 
Induced tree responses lead to multipartite interactions in a community through indirect interactions as one organism may change a host's suitability for others and hosts become less or more suitable for the subsequent attackers. If induced responses increase a tree's defences for a period of time, they are referred to as systemic induced resistance (SIR), whereas when tree resistance declines following attack it is referred to as systemic induced susceptibility (SIS) (Bonello et al. 2006). Bonello et al. (2006) suggested a hypothetical threshold for tree resistance in which an induction event increases defence above the constitutive level, which can remain constant as SIR or decline as SIS. When new herbivores invade an ecosystem, indirect interactions may influence the species' invasive potential because of SIS or SIR from native organism attack or vice versa. Thus, examining tree-mediated interactions may provide insight into the potential interaction of JPBW, MPB, and jack pine.

\section{Systemic induced resistance}

There are many examples of how an initial induction treatment can affect resistance to a subsequent challenge treatment in conifers. For example, pre-treatment of Norway spruce (Picea abies [L.] Karst.) with the blue-stain fungal associate of the Eurasian spruce bark beetle (Ips typographus L.), Ceratocystis polonica (Siem.) C. Moreau induces resistance to simulated bark beetle attack. Inoculation with medium and high fungal densities (50 and 100 inoculations per $\mathrm{m}^{2}$ ) reduced colonization success of a mass inoculation with the same fungus by $76 \%$ and $97 \%$, respectively (Krokene et al. 1999). Likewise, Scots pine was less susceptible to mass inoculation with a blue-stain fungus Leptographium wingfieldii, a fungal associate of the pine shoot beetle (Tomicus piniperda L.), when pre-treated with $L$. wingfieldii (Krokene et al. 2000). Additionally, pre-treatment of Japanese black pine (Pinus thunbergii) and Japanese red pine (P. densiflora) with a non-virulent form of the pine wood nematode Bursaphelenchus xylophilus (Steiner \& Buhrer) Nickle resulted in systemic resistance to a virulent form though high concentrations of pre-treatments were necessary for effective induction (Kosaka et al. 2001).

The defence responses in the studies above could have been organism-specific as the same species was used for the induction and challenge treatments; however, similar results have been observed among multiple species of organisms. In lodgepole pine, defence induction of feeding by the pine beauty moth (Panolis flammea D\&S) and the European sawfly (Neodiprion sertifer Geoff.) were tested on the other species' fitness (Trewhella et al. 1997). Feeding by both insects led to significant changes in needle chemistry, which reduced P. flammea fitness but not that of $N$. sertifer, suggesting that plant defences have different impacts on herbivores. In Finland, Scots pine defoliated by the sawfly Diprion pini (L.) had increased resistance to the pine shoot beetle (Annila et al. 1999).

\section{Systemic induced susceptibility}

There is also research that indicates an initial attack can increase host susceptibility to subsequent attack. At low populations, bark beetles target trees with reduced defences, like those weakened by herbivores and pathogens (Safranyik and Carroll 2006). Heavy defoliation by the Douglas-fir tussock moth (Orgyia pseudotsugata McDunnough) reduced the resistance of Douglas fir (Pseudotsuga menziesii [Beissn.] Franco) to colonization by two bark beetles, a fir engraver beetle (Scolytus ventralis LeConte) and the Douglas-fir bark beetle (Dendroctonus pseudotsugae Hopkins), allowing lower densities of beetles to successfully attack trees (Wright et al. 1984). Wallin and Raffa (2001) examined the effect of JPBW defoliation on colonization by the five-spined engraver beetle (I. grandicollis Eichhoff) and the pine sawyer beetle (Monochamus carolinensis Olivier) in jack pine trees in Wisconsin and found that heavily colonized trees had a reduction in resin flow. Further, beetle-colonized trees coincided with JPBW defoliation, and mortality in colonized trees was positively related to defoliation with $30 \%, 82 \%$, and $100 \%$ mortality in the moderate, heavy, and severe defoliation classes, respectively. Similarly, artificially defoliated red pines were more suitable hosts for the pales weevil (Hylobius pales Herbst) the same year and the pine engraver two years after defoliation compared to the control (Raffa et al. 1998).

There are also examples in the literature demonstrating the complex interactions between species based on the initial damage they caused. For example, defoliation by the pine looper (Bupalus piniaria L.) resulted in a strong decline in the resistance of Scots pine to the blue-stain fungus $L$. wingfieldii (Långström et al. 2001). Trees in the lowest defoliation classes were less susceptible to $L$. wingfieldii than those in higher defoliation classes.

While numerous studies address induced resistance or susceptibility when multiple organisms act on a tree, it is difficult to compare different systems because tree-mediated relationships depend on the interacting organisms, intensity of damage, time since induction, and tree responses to multiple organisms simultaneously. The studies presented above suggest that initial treatment with a pathogen or low defoliation increases tree resistance to fungi and bark beetles, while severe defoliation increases tree susceptibility. If jack pine forests follow this trend, timing of JPBW and MPB interactions will be important for determining whether host resistance or susceptibility was induced by the first attack.

\section{The JPBW - MPB - Jack Pine Interaction}

Predictions of the outcome of the JPBW- MPB - jack pine interaction could be made by examining how MPB and Choristoneura species interact with insects and diseases in their respective forest ecosystems. Attacks by endemic populations of MPB are consistently associated with lodgepole pine infected by Armillaria mellea (Vahl. ex. Fr.) Kummer (Tkacz and Schmitz 1986) or comandra blister rust (Cronartium comandrae Pk.) (Rasmussen 1987). Similarly, lodgepole pine colonized by Monterey pine ips (Pseudips mexicanus Hopkins) were more attractive and a better resource for endemic populations of MPB than those attacked solely by MPB (Smith 2008). Ponderosa heavily affected by south western dwarf mistletoe (Arceuthobium vaginatum [Willd.] Presl subsp. crytopodum [Engelm.] Hawksw. \& Wiens) were at greatest risk for bark beetle colonization in Arizona (Kenaley et al. 2006, 2008). In Newfoundland, the success of the foureyed spruce bark beetle (Polygraphus rufipennis Kirby) in colonizing black spruce (Picea mariana [Mill.] BSP) was positively related to damage by the spruce budworm ( $C$. fumiferana Clem.) and bark beetle attacks increased rapidly 
following the collapse of budworm populations (Bowers et al. 1996). Colonization of jack pine by the five-spined engraver beetle and pine sawyer beetle increase exponentially in relation to JPBW defoliation (Wallin and Raffa 2001).

Although host tree colonization in jack pine forests may initially occur as mass flight events, we assume for the scenarios discussed below that subsequent generations of MPB will establish and persist at endemic levels, as its population growth is likely to be constrained by winter temperatures (Régnière and Bentz 2007). Therefore, established populations will be limited to attacking weakened or stressed trees and MPB spread and survival will be affected by indirect interactions with other organisms in the boreal, which could include those root diseases, such as Armillaria and Tomentosus root rots, dwarf mistletoe (Arceuthobium americanum Nutt. ex Engelm.), competitor beetles, such as pine engraver beetles, JPBW, and other defoliators (Mallet and Volney 1990, Mallet 1992, Brandt et al. 1998).

Since JPBW periodically reaches outbreak levels, changes in its population size could influence stand susceptibility and thus the spread of MPB. If MPB establishes in jack pine forests as predicted, JPBW and MPB could indirectly interact through defence responses in jack pine, which could result in competition or collaboration for shared resources. Since both are agents of large-scale disturbance in their ecosystems, their interaction is important in understanding the behaviour of MPB populations in jack pine ecosystems and cascading effects for other species.

In the same forest, JPBW and MPB will potentially have several periods of temporal and spatial overlap (Table 1). Density-dependent processes affect the generational survival of JPBW (Nealis and Lomic 1994) and MPB (Trzcinski and Reid 2009). JPBW attacks flowering jack pine trees that are over 20 to 30 years of age and there is a strongly positive relationship between pollen cone production and larval survival (Nealis and Lomic 1994). As mentioned, low populations of MPB attack smaller-diameter hosts and those weakened by other organisms, which could include those defoliated by JPBW, but at high populations the MPB attacks healthy mature trees, regardless of their level of resistance. Therefore, temporal overlap in host selection is likely to be important when both populations are at low levels. JPBW and MPB may act synergistically by lowering tree defences (thus increasing tree susceptibility), or they may act antagonistically by raising tree defences (thus increasing tree resistance). The outcome of the JPBW - MPB - jack pine interaction will depend on the population size of each species, host availability, weather conditions, and host suitability, which is influenced by weather and site conditions and any defence response that has been induced. Below we discuss four possible scenarios to generalize interactions between these two species (Fig. 1).

I) If both JPBW and MPB populations were at endemic levels, there would be little effect on the forest stand dynamics. Light JPBW defoliation would minimally impact tree growth (Volney 1988) while MPB would target senescent and weakened trees along with other competitor beetles, such as pine engravers. Low populations would result in a high proportion of unsuccessful attacks (Safranyik and Carroll 2006) and these partial attacks would impact pollen cone production and foliar quality for JPBW larvae feeding in the spring. If JPBW eggs were on a tree attacked by MPB in the late summer, the tree's suitability in the following spring would be altered for JPBW larvae. Pollen cones are critical to the survival of early instar JPBW, so MPB attacks would have an immediate negative effect on budworm survival. Changes in foliar chemistry may also affect adult fecundity (McCullough and Kulman 1991) and thus population levels in the following years. On the other hand, partially attacked trees could produce a stress crop of pollen cones; however, this food source would be unlikely to affect JPBW populations as stress crop trees would be scattered in a stand and it would take several years for JPBW populations to build to destructive levels (Volney 1988). As a result, in this scenario there could be occasional JPBW - MPB interactions but overall the populations of both species would remain low with minimal impact on the forest.

II) If JPBW populations were at epidemic and MPB populations were at endemic levels, trees stressed by heavy defoliation would be preferentially attacked by MPB. The damage to a tree would depend on the induction of jack pine defence, time since defoliation, severity and longevity of defoliation, and the resulting tree condition of resistance or susceptibility to MPB. If heavy or multiple

Table 1. Life cycles of jack pine budworm (NRCan 2010; JPBW) and mountain pine beetle (Safranyik and Carroll 2006; MPB]

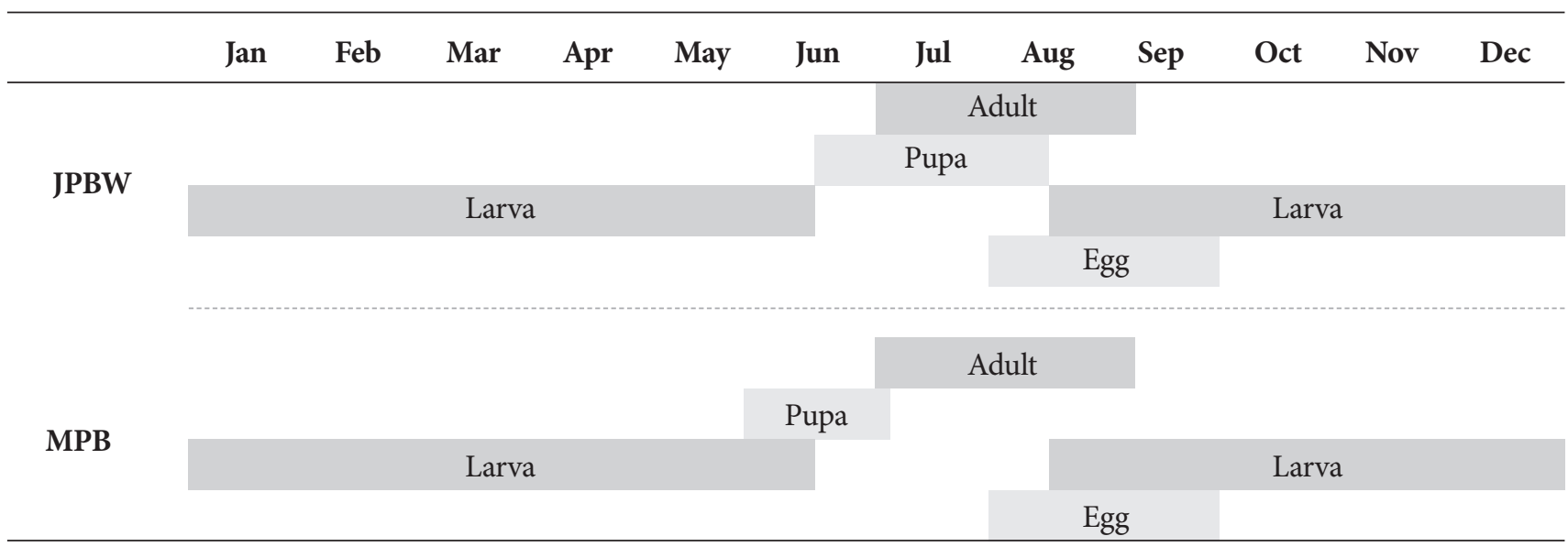




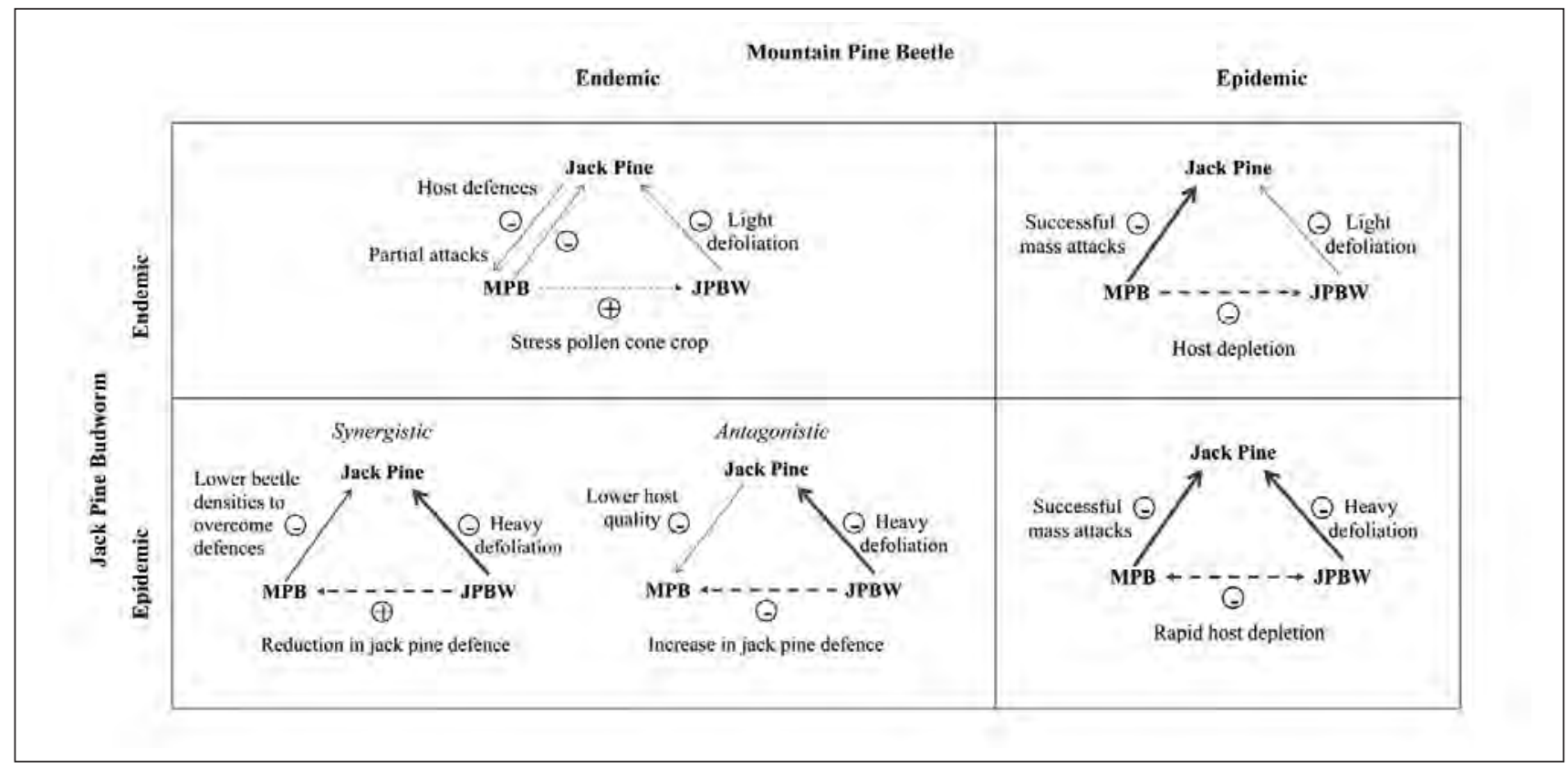

Fig. 1. Illustration of potential tripartite interactions with different population levels of jack pine budworm (JPBW) and mountain pine beetle (MPB) in jack pine boreal forest. Thicker arrows indicate a larger effect.

years of defoliation lower tree defences then lower densities of beetles could successfully colonize and kill a tree (Wright et al. 1984) and would result in higher rates of jack pine mortality than a JPBW outbreak without MPB. MPB populations could build in subsequent years with more successful colonization. On the other hand, if tree defences increase, a much greater proportion of MPB attacks would be unsuccessful and many trees would be only partially attacked. Higher densities of beetles would be necessary to overcome increased defences and successfully colonize a tree, which would negatively impact population growth. As a result, the damage and mortality in stand would be similar to a normal JPBW outbreak as MPB would not add to tree mortality.

III) If JPBW populations were at endemic levels and MPB populations were at epidemic levels, the impact on a stand would be similar to a normal MPB outbreak. MPB would mass attack and kill healthy, mature hosts (Safranyik and Carroll 2006). As mentioned earlier, JPBW oviposits in the summer before MPB colonizes trees and trees with JPBW eggs subsequently colonized by MPB would be dead in the following spring so JPBW larvae would die from starvation as pollen cones would not be produced. JPBW larvae would disperse to find suitable host but the rate of survival would be low. JPBW populations would remain small and may even decrease because of larval mortality and a reduction in the number of host trees. The MPB would continue at epidemic levels with high rates of tree mortality.

IV) It is possible that JPBW and MPB might reach epidemic populations simultaneously. This would have devastating impacts on the forest in a short period of time. MPB would not be affected by defences induced by prior JPBW defoliation because MPB mass attack can overcome even well-defended trees. However, JPBW populations would be sensitive to the timing of MPB outbreak. If MPB populations reached epidemic levels prior to JPBW outbreak, beetle-caused tree mortality and partial attacks would result in JPBW starvation. Trees less desirable for MPB, such as small-diameter trees, would be vulnerable to JPBW defoliation. On the other hand, if JPBW populations were large in the spring prior to MPB flight in the summer, heavy defoliation would kill some trees and those remaining would be attacked by MPB. Outbreaks of both species could rapidly deplete hosts and may lead to the collapse of both populations in the years following.

This model presents a few possible JPBW - MPB interactions at the tree level. We urge the reader to treat this exercise as a first step towards understanding the complex interaction of MPB and JPBW in jack pine forests. Focusing on several basic questions would significantly deepen our knowledge of this interaction. Does defoliation change phloem chemistry in ways that inhibit or promote colonization of jack pine by MPB? Does MPB partial attack affect JPBW larval development and survival though changes in needle chemistry and pollen cone production? How does tree susceptibility change with the intensity and frequency of defoliation and the level of beetle attack: will trees that are moderately to heavily defoliated and then partially attacked by MPB die? Answering these questions will allow us to determine the type of interaction, synergistic or antagonistic, between JPBW and MPB in the boreal ecosystem and provide a platform to examine other aspects of MPB ecology in the boreal. For example, investigations of interactions of MPB with other organisms (e.g., mistletoe, Armillaria) at the tree level would yield a more accurate assessment of invasive potential of MPB in boreal forest. Likewise, understanding the role of host defences and variation in and duration of tree resistance or susceptibility in response to the various types and levels of damage will likely be important. 
We identified the following key issues that should be addressed to better understand MPB ecology in the boreal forest. First, the boreal forest has a very different environment and climate from MPB's historical habitat which could impact the growth, development, and survival of MPB and its associated fungi (Rice et al. 2007). Additionally, since jack pine is a new host for MPB, its phenotypic and genotypic resistance will also affect MPB and its associated fungi. Second, induced responses in jack pine to native insects and diseases will mediate their interactions with MPB, which could influence its success as discussed above. Third, exploring population growth of MPB in jack pine could reveal factors that allow the transition from endemic to epidemic populations as is understood in its historical habitat (Safranyik and Carroll 2006). Finally, in the long run climate change will affect tree phenology (Kramer et al. 2000), forest (Ise and Moorcroft 2010) and insect dynamics (Fleming 1996, Volney and Fleming 2000). These could have interacting effects, for example, asynchrony between jack pine flowering and JPBW larvae emerging from diapauses. Overall, current and planned research in these areas (e.g., http://www.ualberta.ca/ erbilgin/) would allow forest entomologists to make the best recommendations for multi-species management in the boreal with the new challenge of MPB range expansion.

\section{Implications of the Interaction of MPB and JPBW in the Boreal Forest}

Investigating both applied and theoretical interactions between MPB and JPBW in the boreal forest is important for several reasons:

(1) Frequently, management of invasive non-native species focuses on reducing the rate of spread as often species are not detected until after they have established (Liebhold and Tobin 2008). Range expansion of pest species, like the $\mathrm{MPB}$, provide the unique opportunity for the management of invasive species as their behaviour in the new system can be investigated prior to their arrival. A thorough understanding of how a system reacts to the invasion can help forest managers to develop pest management strategies based on the available data. For example, if heavily defoliated jack pine trees are susceptible to MPB attack, these areas can be targeted for sanitation harvesting or other mitigation activities intended to reduce MPB risk. As a result, management of range-expanding species could focus on proactive actions to minimize population growth and slow the rate of spread rather than suppressing outbreaks.

(2) In forestry, while research has focused on the development of resistant trees either using conventional breeding programs or development of transgenic trees (e.g., Sniezko 2006, Lu and Derbowka 2009) few studies have focused on inter-specific interactions mediated by tree defences. Tree-mediated interactions are potentially important determinants of the population dynamics of herbivores and pathogens in forests and may become increasingly important with the effects of climate change. Consequently, studies of the MPB - JPBW - jack pine relationship can be used to better understand ecosystem dynamics as well as to understand the potential risk of invasion of range-expanding species.
(3) The field of chemical ecology plays an important role in the mechanistic understanding of tree-mediated interactions and understanding this relationship is valuable to explain how tree defensive chemistry is regulated and coordinated against multiple organisms, including MPB. Future research in this area will improve a functional understanding of the biochemical consequences of interspecific interactions in invasion ecology and could be used to modify pest interactions.

\section{Acknowledgements}

This paper was supported by NSERC Discovery, NSERC CGS-M, Alberta Ingenuity - New Faculty Award, and the Faculty of Agriculture, Life and Environmental Sciences, University of Alberta, Edmonton, AB. We thank Drs. VJ Lieffers (Department of Renewable Resources, University of Alberta), K.F. Raffa (Department of Entomology, University of Wisconsin, Madison), D.W. Langor (Northern Forestry Centre, Edmonton, $\mathrm{AB}$ ), and an anonymous reviewer for constructive criticism on earlier versions of this manuscript.

\section{References}

[ASRD] Alberta Sustainable Resource Development. 2009. Mountain pine beetle aerial overview 2009. Available at http://www.mpb.alberta.ca/Files/MPB-AerialOverview-2009.pdf [Accessed 24 Jan 2010].

Annila, E., B. Långström, N. Varama, R. Hiukka and P. Niemelä. 1999. Susceptibility of defoliated Scots pine to spontaneous and induced attack by Tomicus piniperda and Tomicus minor. Silva Fenn. 33: 93-106.

Bentz, B.J. and D.E. Mullins. 1999. Ecology of mountain pine beetle (Coleoptera: Scolytidae) cold hardening in the Intermountain West. Environ. Entomol. 28: 577-587.

Berryman, A.A. 1972. Resistance of conifers to invasion by bark beetle-fungal associations. Bioscience. 22: 598-602.

Berryman, A.A., B. Dennis, K.F. Raffa and N.C. Stenseth. 1985. Evolution of optimal group attack, with particular reference to bark beetles (Coleoptera: Scolytidae). Ecology 66: 898-903.

Bleiker, K.P. and D.L. Six. 2007. Dietary benefits of fungal associates to an eruptive herbivore: potential implications of multiple associates on host population dynamics. Environ. Entomol. 36:1384-1396.

Bonello, P., T.R. Gordon, D.A. Herms, D.L. Wood and N. Erbilgin. 2006. Nature and ecological implications of pathogen-induced systemic resistance in conifers: a novel hypothesis. Physiol. Mol. Plant Pathol. 68: 95-104.

Borden, J.H., J.E. Conn, L.M. Friskie, B.E. Scott, L.J. Chong, H.D. Pierce Jr. and A.C. Oehlschlager. 1983. Semiochemicals for the mountain pine beetle, Dendroctonus ponderosae (Coleoptera: Scolytidae), in British Columbia: baited-tree studies. Can. J. For. Res. 13: 325-333.

Bowers, W.W., J.H. Borden and A. Raske. 1996. Incidence and impact of Polygraphus rufipennis (Coleoptera: Scolytidae) in Newfoundland. Forest Ecol. Manag. 89: 173-187.

Brandt, J.P., R.D. Brett, K.R. Knowles and A. Sproule. 1998. Distribution of severe dwarf mistletoe damage in west-central Canada. Can. For. Serv. Spec. Rep. 13. UBC Press, Vancouver, BC.

Bronson, D.R., S.T. Gower, M. Tanner and I. van Herk. 2009. Effect of ecosystem warming on boreal black spruce bud burst and shoot stem growth. Glob. Change Biol. 15: 1534-1543.

[CFS] Canadian Forest Service. 2008. Risk assessment of the threat of mountain pine beetle to Canada's boreal and eastern pine forests. Canadian Forest Service, Pacific Forestry Center: Victoria, BC. Info. Rep. BC-X-417. 
Carroll, A.L., J. Régnière, J.A. Logan, S.W. Taylor, B.J. Bentz and J.A. Powell. 2006. Impacts of climate change on range expansion by the mountain pine beetle. Mountain pine beetle initiative working paper 2006-14. Canadian Forest Service, Pacific Forestry Centre: Victoria, BC. 20 p.

Cerezke, H.F. 1995. Egg gallery, brood production, and adult characteristics of mountain pine beetle Dendroctonus ponderosae Hopkins (Coleoptera: Scolytidae), in three pine hosts. Can. Entomol. 127: 955-965.

Conway, B.E., L.A. Leefers and D.G. McCullough. 1999. Financial evaluation of jack pine budworm outbreak and implications for management. Can. J. For. Res. 29: 382-392.

Duncan, R.W. 2003. Conifer defoliating insects of British Columbia. Canadian Forest Service, Pacific Forestry Center: Victoria, BC. Ann. Op. Rep. Ref. No. R02-30.

Elkin, C.M. and M.L. Reid. 2010. Shifts in breeding habitat selection behaviour in response to population density. Oikos 119: 1070-1080.

Eyles, A., P. Bonello, R. Ganley and C. Mohammed. 2009. Induced resistance to pests and pathogens in trees. New Phytol. 185: 893-908. Fleming, R.A. 1996. A mechanistic perspective of possible influences of climate change on defoliating insects in North America's boreal forests. Silva Fenn. 30: 281-294.

Franceschi, V.R., P. Krokene, E. Christiansen and T. Krekling. 2005. Anatomical and chemical defences of conifer bark against bark beetles and other pests. New Phytol. 167: 353-376.

Goldblum, D. and L.S. Rigg. 2005. Tree growth response to climate change at the deciduous-boreal forest ecotone, Ontario, Canada. Can. J. For. Res. 35: 2709-2718.

Gross, H.L. 1992. Impact analysis for a jack pine budworm infestation in Ontario. Can. J. For. Res. 22: 818-831.

Gross, H.L. and J.H. Meating. 1994. Impact of the 1982-1986 jack pine budworm infestation on jack pine in northeastern Ontario. Canadian Forest Service, Great Lakes Forestry Center, Sault Ste. Marie, ON. Info Rep. O-X-431.

Hunt, D.W.A and J.H. Borden. 1990. Conversion of verbenols to verbenone by yeasts isolated from Dendroctonus ponderosae (Coleoptera: Scolytidae). J. Chem. Ecol. 16: 1385-1397.

Ise, T. and P.R. Moorcroft. 2010. Simulating boreal forest dynamics from perspectives of ecophysiology, resource availability, and climate change. Ecol. Res. 25: 501-511.

Karban, R. and I.T. Baldwin. 1997. Induced responses to herbivory. University of Chicago Press, Chicago, IL. 330 p.

Kenaley, S.C., R.L. Mathiasen and C.M. Daugherty. 2006. Selection of dwarf mistletoe-infected ponderosa pines by Ips species (Coleoptera: Scolytidae) in northern Arizona. West. N. Am. Naturalist. 66: 279-284.

Kenaley, S., R. Mathiasen and E.J. Harner. 2008. Mortality associated with a bark beetle outbreak in dwarf mistletoe-infested ponderosa pine stands in Arizona. West J. Appl. For. 23: 113-120.

Kosaka, H., T. Aikawa, N. Ogura, K. Tabata and T. Kiyohara. 2001. Pine wilt disease caused by the pine wood nematode: the induced resistance of pine trees by the avirulent isolates of nematode. Eur. J. Plant Pathol. 107: 667-675.

Kramer, K., I. Leinonen and D. Loustau. 2000. The importance of phenology for the evaluation of climate change on growth of boreal, temperate and Mediterranean forests ecosystems: an overview. Int. J. Biometeorol. 44: 67-75.

Krokene, P., E. Christiansen, H. Solheim, V.R. Franceschi and A.A. Berryman. 1999. Induced resistance to pathogenic fungi in Norway spruce. Plant Physiol. 121: 565-569.

Krokene, P., H. Solheim and B. Långström. 2000. Fungal infection and mechanical wounding induce disease resistance in Scots pine. Eur. J. Plant Pathol. 106: 537-541.

Kulman, H.M. and A.C. Hodson. 1961. The jack pine budworm as a pest of other conifers with special references to red pine. J. Econ. Entomol. 54: 1221-1224.

Kulman, H.M., A.C. Hodson and D.P. Duncan. 1963. Distribution and effects of jack pine budworm defoliation. For. Sci. 9: 146-157.
Kurz, W.A., C.C. Dymond, G. Stinson, G.J. Rampley, E.T. Neilson, A.L. Carroll, T. Ebata and L. Safranyik. 2008. Mountain pine beetle and forest carbon feedback to climate change. Nature 452: 987-990.

Långström, B., H. Solheim, C. Hellqvist and P. Krokene. 2001. Host resistance in defoliated pine: effects of single and mass inoculations using bark beetle-associated blue-stain fungi. Agric. For. Entomol. 3: 211-216.

Liebhold, A.M. and P.C. Tobin. 2008. Population ecology of insect invasions and their management. Annu. Rev. Entomol. 53: 387-408. Logan, J.A., R. Jacques and J.A. Powell. 2003. Assessing the impacts of global warming on forest pest dynamics. Front. Ecol. Environ. 1: 130-137.

Lu, P. and D. Derbowka. 2009. Breeding eastern white pine for blister rust resistance: A review of progress in Ontario. For. Chron. 85: 745-755.

Malhi, Y., L.E.O.C. Aradão, D. Dalbraith, C. Huntingford, R. Risher, P. Zelazowski, S. Sitch, C. McSweeney and P. Meir. 2010. Exploring the likelihood and mechanism of a climate-changeinduced dieback of the Amazon rainforest. Proc. Nalt. Acad. Sci. 106: 20610-20615.

Mallet, K.I. 1992. Armillaria root rot in the Canadian prairie provinces. For. Can., Northwest Reg. North. For. Cent., Edmonton, Alberta. Inf. Rep. NOR-X-329.

Mallet, K.I. and W.J.A. Volney. 1990. Relationships among jack pine budworm damage, selected tree characteristics and Armillaria root rot in jack pine. Can. J. For. Res. 20: 1791-1795.

McCullough, D.G. 2000. A review of factors affecting the population dynamics of jack pine budworm (Choristoneura pinus pinus Freeman). Popul. Ecol. 42: 243-256.

McCullough, D.G. and H.M. Kulman. 1991. Effects of nitrogen fertilization on young jack pine (Pinus banksiana) and on its suitability of jack pine budworm (Choristoneura pinus pinus) (Lepidoptera: Tortricidae). Can. J. For. Res. 21: 1447-1458.

McCullough, D.G., L.D. Marshall, L. Buss and J. Kouki. 1996. Relating jack pine budworm damage to stand attributes in northern Michigan. Can. J. For. Res. 26: 2180-2190.

[NRCan] Natural Resources Canada. 2009. Canada's forests sustainability indicators: jack pine budworm. Available at http://canadaforests.nrcan.gc.ca/indicator/jackpinebudworm?format=print [Accessed 2009 Sept 14].

2010. Insects and diseases of Canada's forests: jack pine budworm. Available at http://imfc.cfl.scf.rncan.gc.ca/insecte-insecteng.asp?geID=12024 [Accessed 2010 June 18].

Nealis, V.G. 1991. Parasitism in sustained and collapsing populations of the jack pine budworm, Choristoneura pinus pinus Free. (Lepidoptera: Tortricidae), in Ontario, 1985-1987. Can. Entomol. 123: 1065-1075.

Nealis, V.G. 1995. Population biology of the jack pine budworm. In W.J.A Volney, V.G. Nealis, G.M. Howse, A.R. Westwood, D.R. McCullough and B.L. Laishley (eds.). Jack pine budworm biology and management. Proceedings of the jack pine budworm Symposium, Jan 24-26, 1995, Winnipeg, MN. pp. 55-72. Natural Resources Canada, Canadian Forest Service.

Nealis, V.G. and P.V. Lomic. 1994. Host-plant influence on the population ecology of the jack pine budworm, Choristoneura pinus (Lepidoptera: Tortricidae). Ecol. Entomol. 19: 367-373.

Paine, T.D., K.F. Raffa and T.C. Harrington. 1997. Interactions among scolytid bark beetles, their associated fungi, and live host conifers. Annu. Rev. Entomol. 42:179-206.

Parmesan C. 2006. Ecological and evolutionary responses to recent climate change. Annu. Rev. Ecol. Syst. 37: 637-669.

Parmesan, C. and G. Yohe. 2003. A globally coherent fingerprint of climate change impacts across natural systems. Nature 421: 37-42.

Raffa, K.F. and A.A. Berryman. 1983. The role of host plant resistance in the colonization behaviour and ecology of bark beetles (Coleoptera: Scolytidae). Ecol. Monogr. 53: 27-49.

Raffa, K.F., B.H. Aukema, B.J. Bentz, A.L. Carroll, J.A. Hicke, M.G. Turner and W.H. Romme. 2008. Cross-scale drivers of natu- 
ral disturbances prone to anthropogenic amplification: the dynamics of bark beetle eruptions. Bioscience. 58: 501-517.

Raffa, K.F., S.C. Krause and P.B. Reich. 1998. Long-term effects of defoliation on red pine suitability to insects feeding on diverse plant tissues. Ecology 79: 2353-2364.

Rammig, A., A.M. Jösson, T. Hickler, B. Smith, L. Bärring and M.T. Sykes. 2010. Impacts of changing frost regimes on Swedish forests: incorporating cold hardiness in a regional ecosystem model. Ecol. Model. 221: 303-313.

Rasmussen, L.A. 1987. Mountain pine beetle selection of dwarf mistletoe and Comandra blister rust infected lodgepole pine. USDA, Forest Service, Ogden, UT. Res. Note. INT-367.

Régnière, J. and B. Bentz. 2007. Modeling cold tolerance in the mountain pine beetle, Dendroctonus ponderosae. J. Insect Physiol. 53: 559-572.

Rice, A.V., M.N. Thormann and D.W. Langor. 2007. Mountain pine beetle-associated blue-stain fungi are differentially adapted to boreal temperatures. For. Pathol. 38: 113-123.

Safranyik, L. and A.L. Carroll. 2006. The biology and epidemiology of the mountain pine beetle in lodgepole pine forests. In L. Safranyik and B. Wilson (eds.). The mountain pine beetle a synthesis of biology, management, and impacts on lodgepole pine. pp. 3-66. Canadian Forest Service, Pacific Forestry Center: Victoria, BC. Sanders, C.J. 1971. Daily activity patterns and sex pheromone specificity as sexual isolating mechanisms of two species of Choristoneura (Lepidoptera: Tortricidae). Can. Entomol. 103: 498-502.

Smith, G.D. 2008. Maintenance of endemic Dendroctonus ponderosae population through interactions with a secondary bark beetle, Pseudips mexicanus. MSc Thesis, University of Northern British Columbia, Prince George, BC.

Sniezko, R.A. 2006. Resistance breeding against nonnative pathogens in forest trees - current successes in North America. Can. J. Plant Pathol. 28: S270-S279.

Taylor, S.W. and A.L. Carroll. 2004. Disturbance, forest age, and mountain pine beetle outbreak dynamics in BC: a historical perspective. In T.L. Shore, J.E. Brooks and J.E. Stone (eds.). Mountain pine beetle symposium: challenges and solutions, October 30-31, 2003, Kelowna, BC. pp. 41-51. Canadian Forest Service, Pacific Forestry Center, Victoria, BC.

Taylor, S.W., A.L. Carroll, R.I. Alfaro and L. Safranyik. 2006. Forest, climate and mountain pine beetle outbreak dynamics in Western Canada. In L. Safranyik and B. Wilson (eds.). The mountain pine beetle a synthesis of biology, management, and impacts on lodgepole pine. pp. 67-94. Canadian Forest Service, Pacific Forestry Center, Victoria, BC.
Thuiller, W., D.M. Richardson and G.F. Midgley. 2007. Will climate change promote alien plant invasions? In W. Nentwig (ed.). Biological invasions: Ecological studies 193. pp. 197-211. Springer, New York.

Tkacz, B.M. and R.F. Schmitz. 1986. Association of an endemic mountain pine beetle population with lodgepole pine infected by Armillaria root disease in Utah. USDA, Forest Service, Ogden, UT. Res. Note INT-353.

Trewhella, K.E., S.R. Leather and K.R. Day. 1997. Insect induced resistance in lodgepole pine: effects on two pine feedings insects. J. Appl. Entomol. 121: 129-136.

Trzcinski, M.K. and M.L. Reid. 2009. Intrinsic and extrinsic determinants of mountain pine beetle population growth. Agric. For. Entomol. 11: 185-196.

Van der Putten, W.H., M. Macel and M.E.Visser. 2010. Prediction species distribution and abundance responses to climate change: why it is essential to include biotic interactions across trophic levels. Phil. Trans. R. Soc. 365: 2025-2034.

Volney, W.J.A. 1988. Analysis of historic jack pine budworm outbreaks in the Prairie Provinces of Canada. Can. J. For. Res. 18:1152-1158.

Volney, W.J.A and R.A. Fleming. 2000. Climate change and impacts of boreal forest insects. Agric. Ecosyst. Environ. 82: 283-294.

Volney, W.J.A. and D.G. McCullough. 1994. Jack pine budworm population behaviour in northwestern Wisconsin. Can. J. For. Res. 24: 502-510.

Wallin, K.F. and K.F. Raffa. 1999. Altered constitutive and inducible phloem monoterpenes following natural defoliation of jack pine: implications to host mediated interguild interactions and plant defence theories. J. Chem. Ecol. 25: 861-880.

Wallin, K.F. and K.F. Raffa. 2001. Effects of folivory on subcortical plant defences: can defence theories predict interguild processes? Ecology 82: 1387-1400.

Wood, D.L. 1982. The bark and ambrosia beetles of North and Central America Coleoptera: Scolytidae), a taxonomic monograph. Great Basin Nat. Memoirs No. 6, Brigham Young University. 1359 p. Wright, L.C., A.A. Berryman and B.E. Wickman. 1984. Abundance of the fir engraver, Scolytus ventralis, and the Douglas fir beetle, Dendroctonus pseudotsugae, following tree defoliation by the Douglas fir tussock moth, Orgyia pseudotsugata. Can. Entomol. 116: 293-305. 